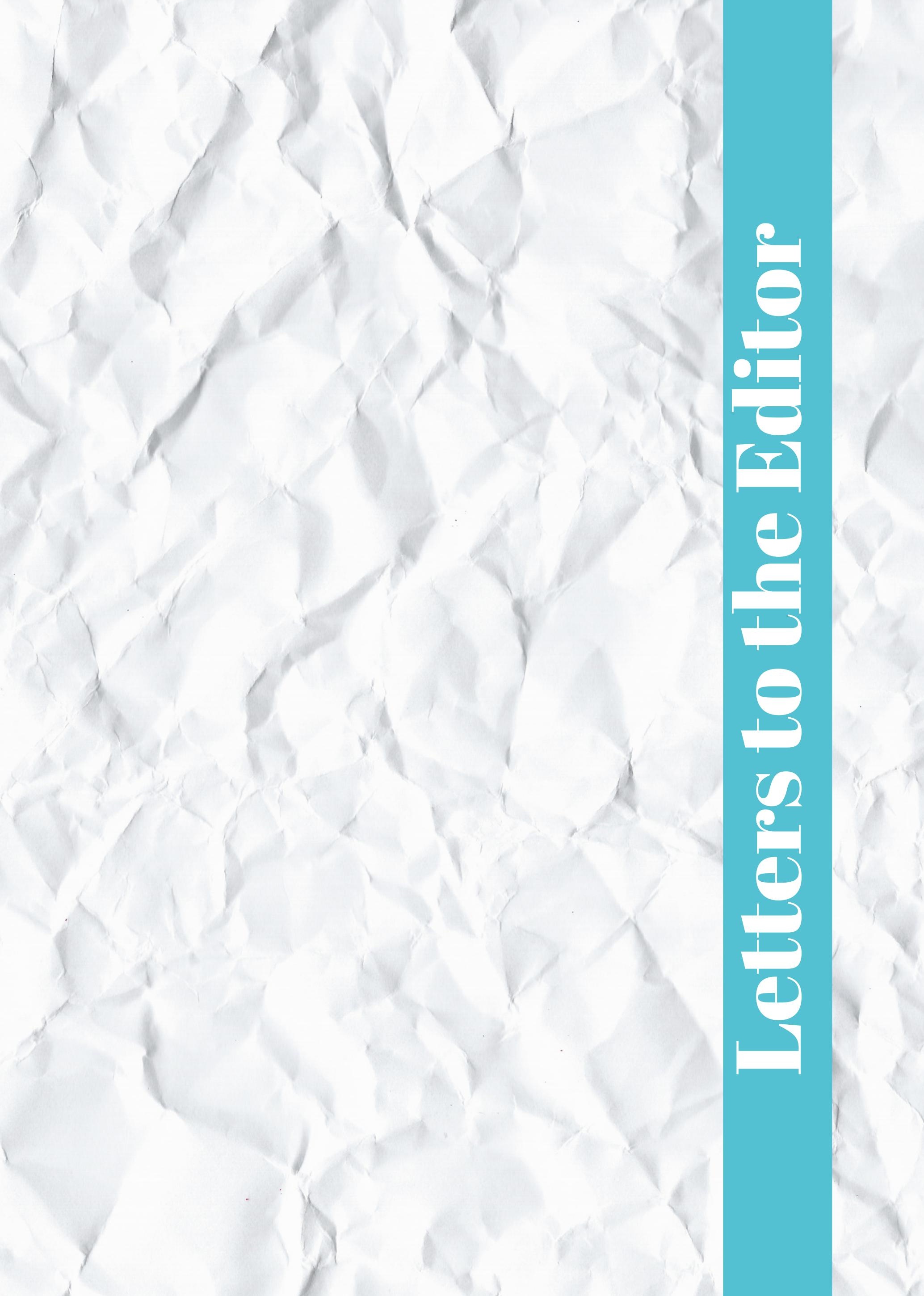




\title{
A Collection of Experiences
}

"As a student, the quarantine has taught me to strengthen my self-learning. It is another way to see the educational field because teachers are not present daily to guide us and answer our questions, as much as we want them to. Instead, we must take advantage of our time and knowledge in a significant and productive way, not only through the activities proposed by our teachers in virtual classes, but also taking into account arts like playing an instrument, singing, dancing, painting, writing, reading, taking pictures, watching movies, and so on... I am a language student, but at this moment, I can be any student as long as I have a good attitude, and I am willing to learn anything. It is something that corresponds to me to motivate others and especially to encourage myself. For those reasons, being a student in this moment means responsibility, commitment, resilience, tolerance, patience, discipline, adaptation, passion for learning, understanding, and empathy. But, the most important thing is to be a conscious student with the current situation and with the self-learning process as a future professional and person."

\section{Laura Camila Salamanca Güechá} Universidad Pedagógica y Tecnológica de Colombia 9th semester Modern Languages Program

\begin{abstract}
"After the pandemic, nothing is going to be the same. At our CAU, we have been creating and using so many different ways to teach and tools, such as social networks (WhatsApp, Facebook), video conferences, and learning platforms among others to keep in touch with our students and support their learning processes. We have learnt so many different lessons, and one of them is that no matter how far you are, there is always someone encouraging you to be better, to not be desperate, and to not give up or panic. Our job here has been like a balm in a desert, in such a way that even from the distance, we continue working as a team. We have learnt to understand others' difficulties, and to take care and help each other in order to work hand in hand and to demonstrate that in hard times we are not alone. We invite all our pre-service teachers to be a new generation of change in teaching because even from the worst situation we could take the best and be better human beings.
\end{abstract}

Yolanda Duarte Medina and Angélica María Carvajal Universidad Santo Tomás CAU Chiquinquirá (Centro de Atención Universitaria) Tutors in the B.A. in English as a Foreign Language 
"Many online English courses are offered year after year. Likewise, there are many apps that allow people to learn any language. During this time, many have taken advantage of this situation in order to promote virtual courses, which is good and a great opportunity to understand those who study through virtual classes. Also, this has been a good opportunity to analyze how close or far we are from using technology as a means to teach, learn, and implement virtual education in our educational system. Many do not have the discipline to study or e-learn through virtual classes. Because nobody is watching us, we open many websites at the same time, we postpone activities, our sister is singing all the time, our brother is watching TV, and our concentration is not easily refocused. Although sometimes we use some basic technology in the classroom (video beam, any app, laptops...), there has not been a moment in which we have primarily needed this resource. We have had to learn everything from creating groups in Whatsapp to sending a simple link to everybody (not copying number by number) to create courses through different platforms, making videos, having video calls with more than one person, etc. However, this time has taught us that, as Vygotsky (1978) stated, social interaction is definitely fundamental in the development of cognition. Many students have learnt English thanks to apps and virtual classes, but they do not have anybody to practice with. Many teachers have learnt how to take advantage of technology, but we miss communicative and interactive sessions, listening to our students, seeing their faces when they do not understand something, inventing words and phrases to say something and then laughing together. We also miss seeing our students playing their roles; the one who always translate everything so that the others can understand the instructions and can work; the one who soars in class because s/he is the one who knows the most; the one who is always lost; the ones who always use the same phrases: 'I like pizza' (but he actually hates it) and 'I like to read in my free time' (but hates it when his says 'for next class you have to read...') among others... Definitely, we humans were born to create knowledge and social relations through interacting with others."

Willian Alexander Mora Mejura Universidad Pedagógica y Tecnológica de Colombia (Sogamoso) M.A. in Language Teaching Graduate 


\section{Cuando todo esto termine, te darás cuenta de....}

"Decreto 192 de 2020, simulacro de cuarentena durante cuatro días. ¡Qué maravilloso! Cuatro días en casa, ninguna excusa para salir.

¿Cuatro días en casa? y ¿si me dan deseos de salir?, ¿de tomar aire? ¿Si me enfermo? ¿Si...pasa algo? Las preguntas anteriores, tal vez, pasaron por la mente de algunas personas que, como yo, sufrimos de una de las enfermedades de moda: la ansiedad. Según dicen, la depresión es exceso de pasado; el estrés, exceso de presente, y la ansiedad, exceso de futuro. Y es, precisamente, en ese futuro, incierto, en el que viví hace algunos años y que ahora, de cuando en vez vivo.

Sin embargo, no solo fue ese Decreto 192, luego vino el 101, el 457 y el 531, y de cuatro días pasamos a estar confinados en nuestras casas, por 39 días. Y... ¿qué me ha pasado? Nada, absolutamente nada.

Pero el querer vivir cada instante del presente, y no permitir que esas ideas de un futuro que no existe lleguen a mi mente y se instalen allí, no es mágico; no es solamente el querer lograrlo. Y es aquí donde cumplo el objetivo de aceptar la invitación a escribir un mensaje, como docente, durante este tiempo que no ha sido fácil. No sabía que la declaración de una pandemia, término que no se escuchaba hacía diez años, nos llevaría a invertir la dedicación de nuestro tiempo. Ahora, ocho horas que se dedicaban a las labores propias de una oficina, unidas a la asesoría a estudiantes, se han visto combinadas con las actividades propias de un hogar. Y es que antes de ser docente, soy madre, esposa, hermana, hija y amiga, papeles que he debido ejercer a la par. Pero no es malo, lo contrario, han ayudado, fuertemente, en mi terapia de vivir cada instante sin la preocupación de qué pasará luego.

Mi trabajo me ha permitido conocer a una gran cantidad de personas, muchas de ellas estudiantes, con este mal a cuestas, y este mensaje es de aliento, es de esperanza y es de evidenciar que sí se puede salir adelante, que cada uno puede ser más fuerte que sus pensamientos, si así se lo propone. Por lo anterior, lo invito a vivir cada momento como desee hacerlo: si le dan ganas de hacer ejercicio, hágalo, y si esa fiebre por hacerlo dura un solo día, no hay problema, disfrútelo, igual. El ejercicio es para Usted, no para lo que otros quieran pensar sobre Usted. Actividades como el pintar mandalas, también me han sido muy útiles y si antes lo hacía solo por descansar, ahora lo hago porque sé que ayuda a sanar, y hasta he descubierto que, como pinto de adentro hacia afuera, es porque me gusta dar a conocer mis emociones. Baile, cante o sencillamente lea lo que le plazca.

Viva lo que Usted quiere vivir, no lo que otros quieren que Usted viva. Cuando todo esto termine, se dará cuenta de que no hubo mejor momento para estar aislado, para retar a sus pensamientos, para dedicarse al único ser que vale ser amado: USTED."

Ilba Yaneth Rodríguez Tamayo 
Dears,

As a teacher of languages, I have been immersed for periods in reading books about language, amazing novels, tales, poems etc. I have done this not just for my studies, but also because over the years, I have linked a pleasurable moment with a book.

Unfortunately, I cannot say or feel the same when I try to link school, in terms of instruction, with my happiest memories. Contrary to that, my experiences with learning in a formal school brings me feelings of insecurity and a lack of confidence. Several times, I have had tasks that have lacked realistic thinking and have been full of unnecessary strain to feel, at the end of the day like what W. W. Sawyer mentioned in his book, "Mathematician's Delight", a howler impossible to do something well.

However, I have to thank all of my institutions where they taught me all that I know in relation to pedagogy, language, and books. After all, they taught me to read, in both languages, Spanish and English. The pleasure of learning just happened out of luck.

Over time, I, as a teacher, understood that the process of learning any subject in an effective way demands a combination of factors:

Appealing and interesting messages, the success of security, realistic thinking, and so on. But you might be thinking that there is no point in writing a reflection paper about being critical of the teaching and education during the pandemic.

First of all, I am totally conscious about our current situation. However, I can see the enormous opportunity to make relevant changes in our lives knowing the reasons why. You and I know that not only education as a system needs to be reexamined, but also the way we study needs to be reconsidered.

What are we studying the whole day for? What do we really want to do as professionals? Are we, as a learners, doing our best in order to use thinking as a real tool?

I consider this time as an opportunity to teach naturally, where the best method to learn things is following our passion, effort, and hearts. Doing so helps us realize that humans are allowed to be imperfect in order to learn from the errors. This time is the perfect time to learn, because now we can reason with everything without excuses.I hope these words not only express my insights, as a teacher, about teaching and learning, but that these words also move us toward a transformation of our learning and teaching as a delightful practice. Let's take advantage of this situation to create, to do things with effort, to make things with love, to notice things with passion and arrange things, following the same extraordinary road that our human species has followed for years, the magnificent road of reason with everything. 


\section{Does online teaching make online learning a good experience?}

"It is often said that education has a crucial role in the development of people's lives that comes from a relationship between learning and teaching. These processes have been transformed and adapted according to some situational aspects. For this reason, it is vital to mention how online teaching has an impact in the field of online learning and how its own development affects measurable outcomes. Moreover, this growth process has been modified during this time not only by the aspects of communication, but also by factors that can be excluded, which affect all kinds of developmental processes. In this written text, I will give my opinion about the situation that we are facing in 2020, and how online teaching and learning can fit into the idiom "the cure could be worse than the disease".

The internet has changed our lives providing facilities to solve issues in different situations. For this reason, we have several ways to be in contact with people, despite the conditions of living. Nowadays, we are exploring new ways of communication with people through platforms on the internet. We can communicate with people in any place and at any time. Certainly, throughout time, people have found ways to feel like an important part of the international development. Here, the internet serves as a means to connect people where they can feel comfortable in the field that they are immersed in. So, it is vital for their own improvement. It all sounds good, doesn't it?

Education is an important field for human development. People usually learn in different ways through an interaction that arises the creation of social development. Education has overcome several aspects that give a new balance about what people live and how they can use it to learn. During the acquisition process, there is a relationship between learning and teaching, where each one of them has particularities that help complete the process for each one. Teaching creates a connection through knowledge in a comfortable context. Learning is successful where all conditions to learn are based on the need of who learns. Sometimes where teaching is useful the learning process is unsuccessful. During this time, education has provided a new perspective about what people usually do and how it complements their own learning process. Now, there is an alternative to be immersed in the real world since different platforms, virtual or in person, complement the other.

The internet has become a means for education to develop its own outcomes. People have developed ways to be successful with the demands of the world. That it is why, the internet has become a means to help fulfil the process of learning. Nowadays, the internet has been used to virtualize classes as a way to keep people learning, but this is not an absolute truth! You need to know that it is not all the same as it was before. During this time, we have lost ways of learning and teaching because of social distancing. As mentioned before, this process of learning through the internet is a way to complement the learning process that we have in classrooms and daily life. There is a widespread belief about what we need to learn is theories about the knowledge of the world, but we forget that during this time we are learning, too. We do not need an academic context to get knowledge that will be appreciated by us beyond our academic lives. We need excellent human beings, and it is what we have to learn at this moment. 
The cure is worse than the disease in a world that is closed around personal development for the development of the world. This is a time for a change, from personal to social experience. We are facing a different situation right now; that is why the the relation between online teaching and learning cannot be as perfect as it was lived before in education. There are circumstantial factors that do not allow for flexibility, freedom, or self-directedness during the learning process. We feel suffocated, frustrated, pressured and captive. Probably, it is not the best way to take advantage of online learning as we are not living under normal conditions. Sometimes, these processes are not meant to be a guide, not from this side. There is an imposition that turns into a human being without any sense. There is an option of virtual classes, at the end of the day, that ends up suffocating more than the issue of the pandemic outside. We can use the internet to complement a process of learning, but not as a complete process due to the lack of real immersion.

Viviana Angélica Ramos Pedraza Universidad Pedagógica y Tecnológica de Colombia Modern Languages Program 


\section{Isolation as a Growing Time}

At twenty-six, I thought that many of my dreams, goals, and expectations had been ruined by a pandemic. The days and months began to pass slow inside my home, and I realized that all of my attention was on a future vision, not so much on the present. I was wrong because it is always necessary to know our own soul in order to understand how much we can bear ourselves and our loneliness. Besides, the misfortunes, the tragedies, and the pain are a test to leave indifference and selfishness; we can open our eyes and feel the suffering of a whole world. There is nothing more satisfying than appreciating the closed and silent city as a sensitive space to animate our inner being, and not as a place of fear of contagion. It is not about wasting time; it is about feeling and valuing it, taking into account what we can give of ourselves in the present.

I accept, I do feel the absence of many things that make me feel full. For instance, studying makes me feel like this. I miss sitting in a classroom exchanging the language of learning always accompanied by laughter. I would also like to be in some green area of the university talking to my friends on days like today. We would be talking about homework, music, books, and life. Moreover, I even miss walking from home to the university. I do not want to be hundreds of kilometers away from people anymore. I am sure that this isolation will not be in vain. I keep reflecting and feeding my morale. I hope that thanks to this lesson we return to live with more passion and intensity. Above all, I hope to see a better reality where I can continue growing and ... growing.

Lina María Calixto

Universidad Pedagógica y Tecnológica de Colombia

Modern Languages Program

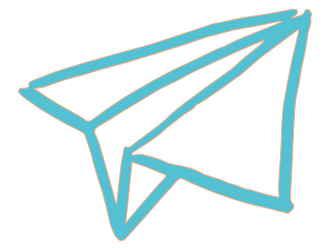




\section{A New Version of Myself: My Experience Teaching English During a Worldwide Quarantine}

2020 has become a year in which too many people have had to change their lifestyles because of a world pandemic. COVID-19 appeared to change the world in many different settings as it changed filled schools, soccer fields, main streets, and workplaces into empty ones. On March 24th, our government decided to implement a quarantine in order to avoid spreading this virus, which in my case, has affected teaching and learning processes. Unfortunately, it has also killed thousands of people all over the world.

As a citizen, I consider decisions have been made correctly. If humans do not avoid contact with others, this virus will spread out in a very short period of time and people's lives will be at risk. Hence, schools had to close their doors and continue those learning processes, virtually. As an English teacher, I had to re-signify my teaching as I knew my students' acquisition processes would not be accepted easily if I continued teaching the same way I used to do in class.

When we were at the school, I noticed they were not really aware about the importance of learning another language. Therefore, I opened my eyes and realized different ways I needed to adapt myself if I wanted to get my students' attention in our new online classes. This new effort I decided to make helped me construct a new version of myself because at home, students have the chance to be distracted easily as they are not used to having classes virtually.

For instance, at the very beginning of this new learning environment, I proved myself I was right! Learners' attention was hard to control as they found the chance to do something different in class, such as use their cellphones to play games while I was trying to explain a topic or talk amongst themselves about unknown things I will never know. Laughter came spontaneously, and it was the key issue that made me stop my online classes and start accepting. At that point, I understood that they were actually facing this new challenge in the same way that I was learning how to do it. It is easy to judge them, however, once I was able to stand in their shoes, I comprehended that they missed their friends as they used to interact day after day with them.

As a result of this experience, adapting myself to their conditions helped me succeed in this new learning context. I learned that involving their cellphones in their learning process was an advantage for me. Instead of pushing them to listen to me the whole time, I decided to create this learning atmosphere in which they were aware of the advantages of using technological tools in their English learning processes.

Mairon Felipe Tobar Gómez Universidad de la Amazonia Florencia Caquetá, Colombia 


\section{Love in the Time of COVID}

This is not a common love story. There will be no two households, both alike in dignity. And there will not be a tall ivy colored wall for our love-interest to climb, so that he can rob precious minutes with dear Juliet. Because after all, this is a love story in the time of COVID.

Florentino donned his ruana as Argos waited impatiently by the door staring at his leash. Florentino fiddled with his keys, which were much harder to use now that he had to wear gloves every time he took the dog outside. By the time Florentino and Argus had reached the park, Florentino realized that he forgot to bring a bag to clean up after Argo, but time was not on his side. He would not risk the 20 minutes of allotted "outside time" just to go all the way back home for a bag. Just when he thought that all hope was lost, an angelic, albeit muffled because of the mask, voice hit Florentino like a ton of bricks. "Here I have an extra bag". It was Fermina. Her family and Florentino's did not get along. Something about an old family feud.

They knew that they could not go against the wishes of their families, but it was love at first appropriately distanced sight. They agreed that they would meet through their windows that night. Fermina had never realized how handsome Florentino was. However, that night, with the moon bouncing playfully off his mask, and the way his glove covered hand grazed hers when had taken the bag, she knew it was love. They continued meeting in secret 20-minute intervals outside and having clandestine appointments through their windows, until one day when Fermina did not show up.

Florentino was distraught. He did not understand why she had abandoned him. Her ID number ended in five and it was her day to go outside, so he did not understand what could have happened. Had she been taken from him by.... the virus? Unbeknownst to Florentino, Fermina's father had married her off to a rich doctor that worked at San Rafael hospital, to ensure her and her families' safety.

Years passed, and with them the virus. Fermina, finally free from gloves and masks, was taking her dog Fang for a walk. Ever since the pandemic, she enjoyed leisurely walks outside where she would think about a life that once was, and a love that was lost. Consumed by her introspection, she had left home without a bag for Fang. Frantic, she searched the park for a spare bag when a voice, unencumbered by a mask, pierced her concentration. A familiar hand reached out to her as if it had traveled through time. Though now wrinkled and free from its white latex prison, it was unmistakable, and Fermina's heart skipped a beat. "Here I have an extra bag". 